\title{
The tropical Atlantic surface wind divergence belt and its effect on clouds
}

\author{
Y. Tubul, I. Koren, and O. Altaratz \\ Department of Earth and Planetary Sciences, Weizmann Institute of Science, Rehovot, Israel \\ Correspondence to: I. Koren (ilan.koren@weizmann.ac.il)
}

Received: 5 August 2015 - Published in Earth Syst. Dynam. Discuss.: 26 August 2015

Revised: 8 November 2015 - Accepted: 17 November 2015 - Published: 14 December 2015

\begin{abstract}
A well-defined surface wind divergence (SWD) belt with distinct cloud properties forms over the equatorial Atlantic during the boreal summer months. This belt separates the deep convective clouds of the Intertropical Convergence Zone (ITCZ) from the shallow marine stratocumulus cloud decks forming over the cold-water subtropical region of the southern branch of the Hadley cell in the Atlantic. Using the QuikSCATSeaWinds and Aqua-MODIS instruments, we examined the large-scale spatiotemporal variability in the SWD belt during a 6-year period (2003-2008) and the related links to cloud properties over the Atlantic Ocean. The Atlantic SWD belt was found to be most pronounced from May to August, between the Equator and $2^{\circ} \mathrm{N}$ latitude. A positive correlation and a strong link were observed between formation of the SWD belt and a sharp sea-surface temperature gradient on the northern border of the cold tongue, supporting Wallace's vertical-mixing mechanism. The dominant cloud type over this region was shallow cumulus. Cloud properties were shown to be strongly linked to the formation and strength of the SWD zone. The findings will help to understand the link between ocean-atmosphere dynamics and cloud properties over this region, and suggest that the SWD zone be considered a unique cloud belt of the southern branch of the Atlantic Hadley cell.
\end{abstract}

\section{Introduction}

The Intertropical Convergence Zone (ITCZ) is located north of the Equator throughout the year over the eastern tropical Pacific and Atlantic oceans (Hu et al., 2007). This defines an interesting narrow belt bounded by the geographical Equator and the ITCZ. Both oceanic and atmospheric processes along the geographical Equator are affected by changes in the magnitude and sign of the Coriolis force. The ITCZ marks the warmest sea-surface temperatures (SSTs) where the Hadley cells converge. The narrow band between the Equator and the ITCZ is therefore controlled by a unique set of oceanic and atmospheric features. As a part of this band there is an area with a zonal belt of surface wind divergence (SWD) that is seen during the boreal summer months (JJA; Hastenrath and Lamb, 1978; Risien and Chelton, 2008; Zhang et al., 2009). The SWD strongly affects the properties of clouds that form over and near it. In this study, we propose that this oceanic region be considered a unique cloud belt in the southern branch of the Atlantic Hadley cell.
Specifically, this narrow belt is bounded by the oceanic cold tongue that forms over the Equator during the boreal summer months (Mitchell and Wallace, 1992) and the warmer ITCZ waters (see Fig. 1a). Studies on the coupling between SST and the magnitude of surface winds clearly show a positive correlation on spatial scales of $25-1000 \mathrm{~km}$ (e.g., Small et al., 2008; Chelton and Xie, 2010). The trade winds accelerate as they blow over the SST gradient from cold to warm water. Such acceleration implies an increase in the mass flux out along the wind trajectory that drives local SWD and therefore subsidence of the air mass from above (Fig. 1b). This belt of wind divergence is located (on average) between latitudes 0 and $2^{\circ} \mathrm{N}$.

Two main scenarios have been suggested to explain the link between SST, surface wind speed, and the formation of SWD, the first by Lindzen and Nigam (1987) and the second by Wallace et al. (1989). While both hypotheses explain how the change in SST affects the surface winds to form SWD, each of these mechanisms suggests a different location for 
a)

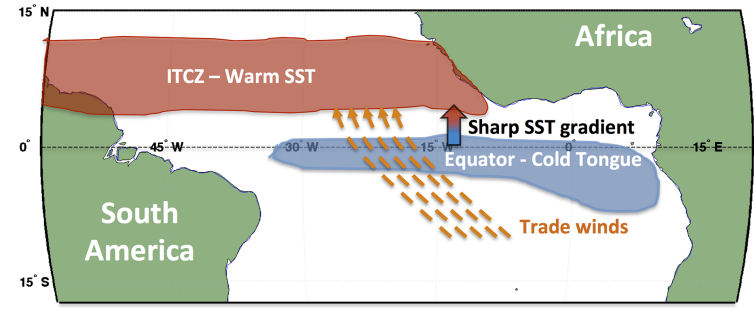

b)

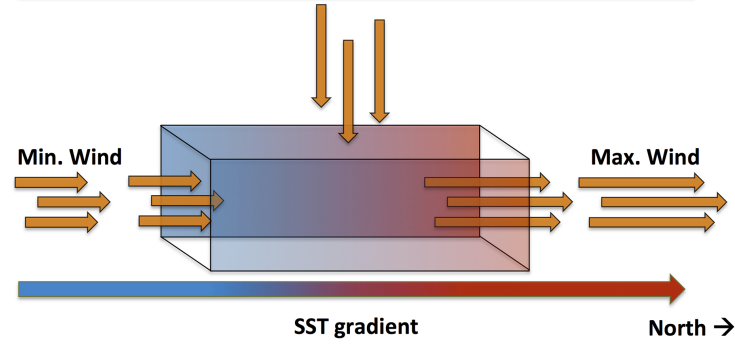

Figure 1. (a) A schematic map of the main tropical Atlantic players from May to August. (b) A north-south cross section along the narrow band between the equatorial cold tongue and the Intertropical Convergence Zone (ITCZ) showing acceleration of the trade wind path along the sharp sea-surface temperature (SST) gradient which imposes surface wind divergence.

the SWD. The first hypothesis suggests that the SWD should overlap the cold SST (i.e., cold tongue) and the second hypothesis links it to the cold-to-warm SST gradient. Figure 2 presents the mean monthly SST for July 2007 in the equatorial Atlantic Ocean (black contours) and the mean SWD field (color). In agreement with the theory of Wallace et al. (1989), anomalous positive values of mean SWD (red coloring) in July are positioned over the sharp SST gradient on the northern border of the Atlantic cold tongue (Fig. 2a). Moreover, when the equatorial cold tongue and the sharp SST gradient are absent (in October, for example), the SWD belt does not appear (Fig. 2b).

Previous studies have indicated that the northern and southern borders of the cold tongue are characterized by a pattern of westward-propagating waves termed tropical instability waves (TIWs). This is observed in both the Atlantic (Düing et al., 1975) and Pacific (Legeckis, 1977) oceans. These waves form in response to intensification of the southeasterly trade winds and the onset of the equatorial cold tongue during the early boreal summer months. Hayes et al. (1989) tested the hypothesis of Wallace et al. (1989) and explored how the variability in SST in the eastern Pacific TIW influences the surface winds. They showed high correlations between the meridional SST gradient and the wind speed gradient along the same direction. They also showed that the northern border of the cold tongue is the region with the sharpest SST gradient and the strongest SWD. More recent works corroborate this coupling from satellite observations of SST and high-resolution scatterometer measurements of surface winds in the Pacific and Atlantic cold
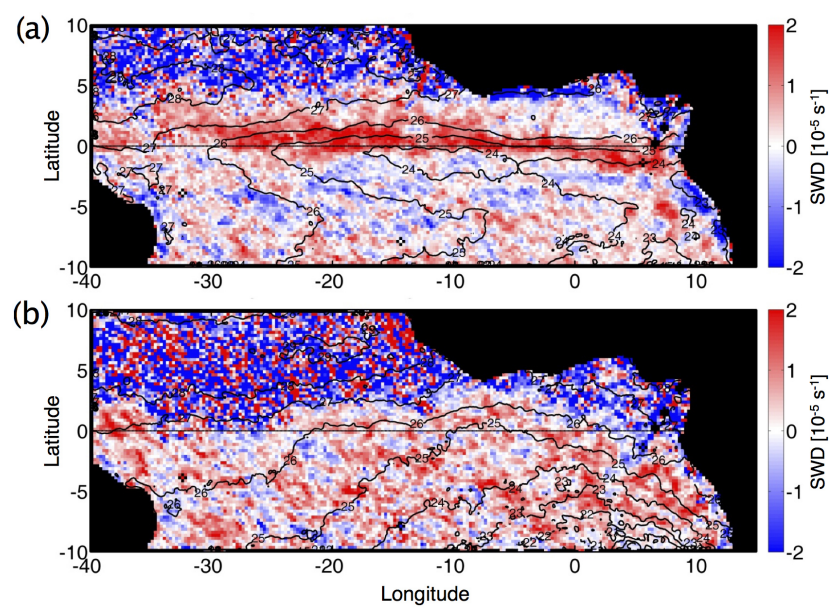

Figure 2. Tropical Atlantic monthly maps of mean surface wind divergence (in units of $10^{-5} \mathrm{~s}^{-1}$, color) and sea-surface temperature $\left({ }^{\circ} \mathrm{C}\right.$, black contours) for (a) July and (b) October 2007, using QuikSCAT-SeaWinds and MODIS-Aqua.

tongues (Xie et al., 1998; Chelton et al., 2001; Hashizume et al., 2001).

Moving northward from the equatorial cold tongue, the atmospheric conditions change gradually. Aircraft measurements at $30 \mathrm{~m}$ height in the eastern equatorial Pacific (along $95^{\circ} \mathrm{W}$ ) showed nearly zero latent and sensible heat fluxes over the cold tongue waters $\left(\sim 18^{\circ} \mathrm{C}\right)$ and maximal heat fluxes of 160 and $30 \mathrm{~W} \mathrm{~m}^{-2}$, respectively, over the warmer waters $\left(\sim 24^{\circ} \mathrm{C}\right.$ ) around $2^{\circ} \mathrm{N}$ (de Szoeke et al., 2005). Additional observational studies for the same geographical region (Zhang and McPhaden, 1995; Thum et al., 2002; Small et al., 2005) estimated changes in fluxes in the range of $6.5-7.5 \mathrm{~W} \mathrm{~m}^{-2}$ in sensible heat flux and $25-35 \mathrm{~W} \mathrm{~m}^{-2}$ in latent heat flux both for $1{ }^{\circ} \mathrm{C}$ change in SST. Over the same region, observations of the marine boundary layer (MBL) depth based on a radiosonde transect along $2^{\circ} \mathrm{N}$ showed vertical displacement of the inversion layer base height from $1 \mathrm{~km}$ over the cold water of the TIW $\left(126^{\circ} \mathrm{W}\right)$ to $1.5 \mathrm{~km}$ over the warm water $\left(123^{\circ} \mathrm{W}\right)(\mathrm{Xie}, 2004)$. Increased water vapor content over warm water, as well as increased cloud liquid water content and rain amount, was observed in an 8year study over the Atlantic TIW (Wu and Bowman, 2007). The deepening of the atmospheric MBL and the increase in heat and water vapor fluxes moving from the cold tongue to warmer water favors the formation of marine stratocumulus clouds, as observed from satellite images (Deser et al., 1993). In agreement, Mansbach and Norris (2007) described a decrease in the amount of low-level clouds over the Pacific cold tongue when it is well defined, highlighting the frequent formation of cloud-free boundary layers over the cold tongue.

The strength of the inversion layer and SST have been shown to be main players in determining the atmospheric conditions, and hence cloud properties, over the subtropical oceans (Albrecht et al., 1995; Myers and Norris, 2013). 
Under conditions of cold SST and low inversion, inversiontopped marine stratocumulus clouds will form in a structure of closed cells and be maintained by downdrafts driven by cloud-top radiative cooling (Wood, 2012) and turbulent mixing in the cloud layer (Bretherton and Wyant, 1997). This gradually transforms into an open cell structure and then into trade cumulus clouds while moving to regions with warmer water (dictating larger fluxes) and, at the same time, the MBL inversion climbs and becomes weaker (Wyant et al., 1997). Such transitions are valid as one moves westward or southward (toward the Equator) from the eastern shores of the subtropical oceans off Africa or America, with upwellingdriven cold SSTs, experiencing gradual warming of the SST and deepening of the MBL. This transition is characterized by a distinct decrease in cloud cover with a minimum over the trade cumulus regime (Muhlbauer et al., 2014). Figure 3 shows the ITCZ and shallow marine stratocumulus (MSc) cloud regimes characterized by high cloud cover and the decrease in cloud cover between them.

Here we argue that, when examining meridional features of the southern branch of the marine Hadley cell, the special zone discussed here, located between the cold tongue and the ITCZ, should be considered a unique zone with special wind and cloud patterns.

\section{Data and methods}

Observational data retrieved from high-resolution active and passive satellite instruments were used to specify the equatorial SWD belt, cold tongue, and cloud properties. Analyses were based on a full 6 years of daily data collected from 2003 to 2008 .

The SWD was calculated using $0.25^{\circ} \times 0.25^{\circ}$ resolution surface wind measurements from the SeaWinds active microwave scatterometer instrument on board the QuikSCAT (Quick Scatterometer) satellite. Launched in 1999 (Spencer et al., 2000), SeaWinds passes twice a day (06:30 and 18:30 local time (LT)), measuring surface wind speed and direction at $10 \mathrm{~m}$ above sea level. The SWD was defined using a divergence term (Eq. 1):

$\mathrm{SWD}=\partial u / \partial x+\partial v / \partial y$,

where $u$ and $v$ are the zonal and meridional components of the wind. Wind divergence is presented in units of $\mathrm{ms}^{-1}$ per distance of $1^{\circ}(\sim 100 \mathrm{~km})$, which is equal to $10^{-5} \mathrm{~s}^{-1}$. The monthly mean divergence ranged mostly between 2 and $-2 \times 10^{-5} \mathrm{~s}^{-1}$, where negative divergence is referred to as convergence. Examining the ITCZ through the SWD showed that it is characterized by mean values of around $-1.5 \times 10^{-5} \mathrm{~s}^{-1}$ during most of the year (Fig. 4). QuikSCAT provides surface wind data under both clear and cloudy conditions, but possible errors can be caused by rain (Draper and Long, 2004). The monthly mean SWD values used here were calculated using daily data.
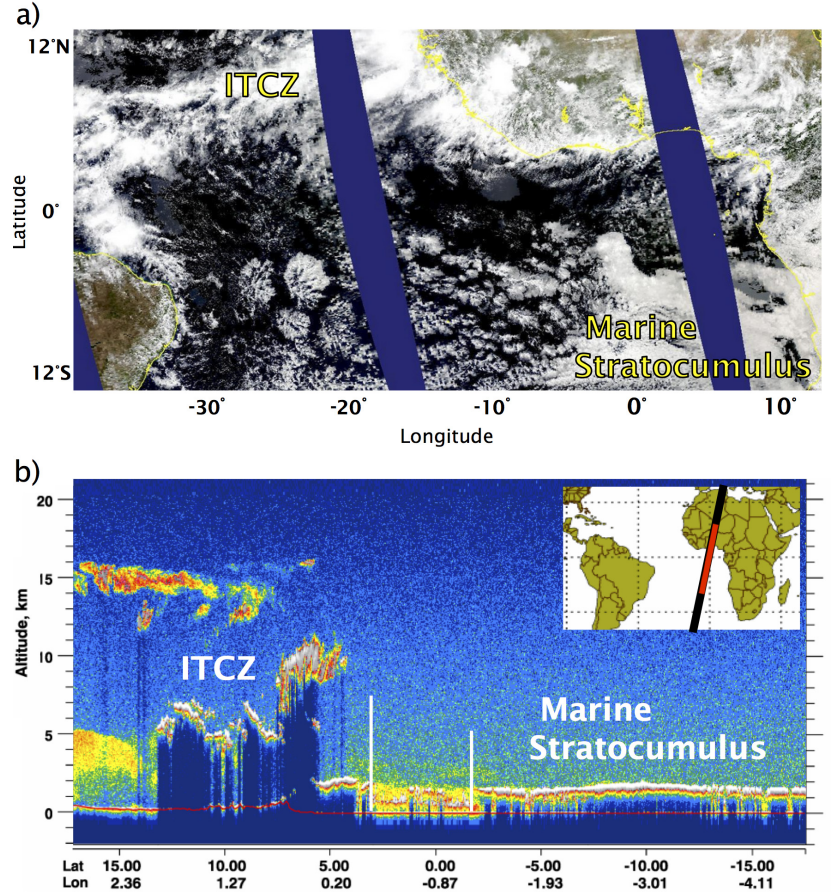

Figure 3. (a) Aqua MODIS true color image (RGB) of the tropical and Southern Hemisphere subtropical Atlantic Ocean on 8 July 2012. (b) CALIPSO CALIOP $532 \mathrm{~nm}$ total attenuation backscatter presenting a vertical profile of cloud and aerosol while crossing the eastern Atlantic Ocean on the same day. Note the area of relatively lower cloud amount between the tropical deep convective clouds and subtropical marine stratocumulus decks.

SST (Esaias et al., 1998) and cloud properties (cloud optical thickness (COT) and cloud fraction (CF); Platnick et al., 2003) were obtained from the Moderate Resolution Imaging Spectroradiometer (MODIS) instrument on board the Aqua satellite (equatorial crossing at 01:30 and 13:30 LT).

Our research domain was set to cover the equatorial Atlantic cold tongue and the SWD belt. Therefore, an area between $10^{\circ} \mathrm{N}$ and $10^{\circ} \mathrm{S}$ is presented in the first part of the Results section. The focused investigation of the SWD belt was performed over a subset of this area located in the central Atlantic $\left(20-10^{\circ} \mathrm{W}\right)$, between 0 and $2^{\circ} \mathrm{N}$ latitude, covering the belt of maximum mean SWD (Fig. 4a).

\section{Results}

The spatial association between SST, SWD, and cloud properties (COT and CF) was examined first. Figure 4 presents maps of mean monthly SWD, cloud properties (colors), and SST (black contours) for July 2007. The SWD belt (colored in red) is evident (Fig. 4a) along the sharp SST gradient at the northern border of the equatorial cold tongue. Note that the TIW cannot be recognized in a monthly average SST field due to the same (monthly) characterization timescale of this phenomenon. High SWD values $\left(>1.5 \times 10^{-5} \mathrm{~s}^{-1}\right)$ can 

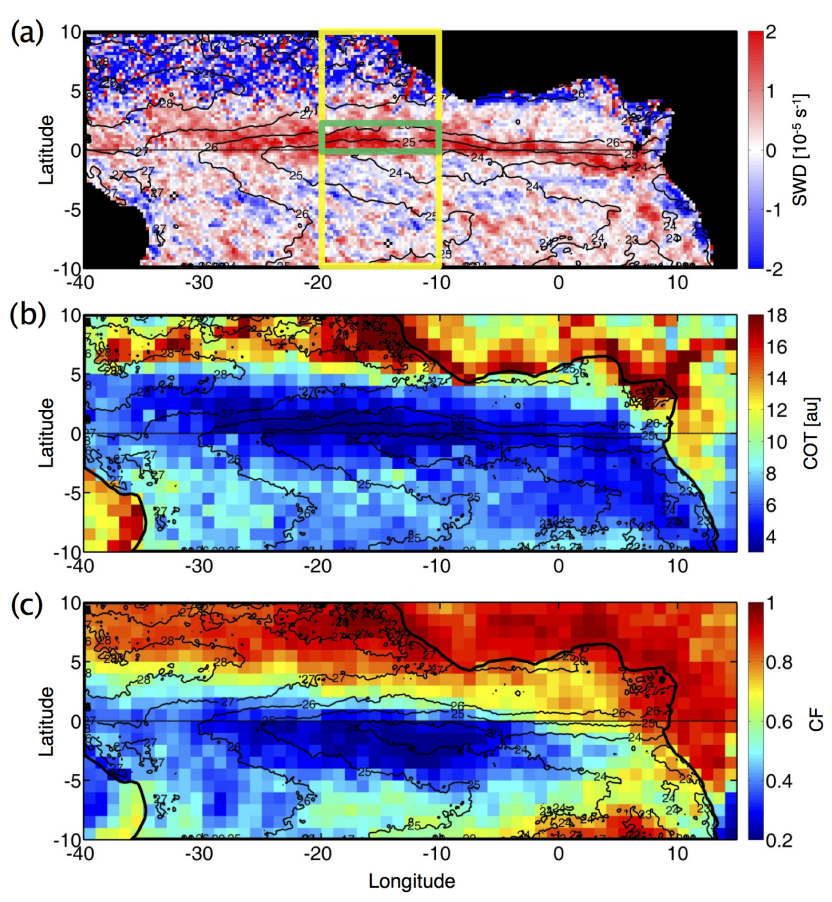

Figure 4. Monthly mean maps of (a) surface wind divergence (in units of $10^{-5} \mathrm{~s}^{-1}$ ), (b) cloud optical thickness (in arbitrary units), and (c) daytime cloud cover fraction (normalized units between 0 and 1) during July 2007. SST $\left({ }^{\circ} \mathrm{C}\right)$ is presented as black contours in all panels. The yellow and green boxes in Fig. 4a define the areas focused on in Figs. 5 and 6.

be recognized slightly south of the Equator over the eastern Atlantic, and between latitudes $0^{\circ}$ and $2^{\circ} \mathrm{N}$ over the central Atlantic. Strong convergence dominates over the ITCZ belt north of latitude $5^{\circ} \mathrm{N}\left(<-1.5 \times 10^{-5} \mathrm{~s}^{-1}\right)$ as well as in the area south of the Equator, induced by the warm-to-cold SST gradient. Two fundamental properties of clouds are presented as well - the COT (Fig. 4b) and daytime CF (Fig. 4c).

The deep convective clouds over the ITCZ (COT > 10), as well as in the western subtropical Atlantic (COT $>7$, colored in turquoise-yellow), were characterized by high COT. As the eastern subtropical SST gets warmer toward the west or toward the ITCZ, the MBL becomes deeper, permitting formation of thicker low clouds $(5<\mathrm{COT}<10)$. A cloudy area characterized by relatively low COT $(<5)$ formed between the subtropical and ITCZ belts, with the lowest values centered along the sharp SST gradient (the SWD belt).

The map of CF spatial distribution (Fig. 4c) presents high values over the deep convective ITCZ belt (with $\mathrm{SST}>27^{\circ} \mathrm{C}$ ) and over the subtropical eastern Atlantic (with SST $<24^{\circ} \mathrm{C}$ ), whereas over the belt between them, the cloud cover was significantly smaller. Specifically, the lowest CF values $(<0.4)$ were between latitudes 5 and $0^{\circ} \mathrm{S}$, overlapping the cold tongue area.

We examined the annual variability in the SWD belt and cloud properties in the central Atlantic between longitudes
20 and $10^{\circ} \mathrm{W}$ (defined by the yellow square in Fig. 4a). Figure 5 presents Hovmöller diagrams for the years 2003 2008. The upper panel (Fig. 5a) shows the changes along the years in the position and magnitude of the SWD. In this domain (i.e., the central Atlantic), the SWD forms around May-June and remains until August-September. It is prominent between the Equator and $2^{\circ} \mathrm{N}$ latitude. The patterns of the SWD belt correlate with the migration of the ITCZ belt in the Northern Hemisphere (as illustrated by the blue coloring in Fig. 5a). The ITCZ belt is positioned closer to the Equator during the months of December-April, and in May, it migrates northward, reaching its most poleward northern position during July-August. This is when high values of SWD $\left(>1.5 \times 10^{-5} \mathrm{~s}^{-1}\right)$ appeared (while the ITCZ moved northward, May-July), suggesting a link to the sharpest meridional gradient in the SST that forms during this period. Later, when the ITCZ migrated back toward the Equator, the SWD belt was still evident but in a weaker form $\left(\sim 0.5 \times 10^{-5} \mathrm{~s}^{-1}\right)$ and with smaller meridional extent. The SWD was not evident between December and April, when the ITCZ was in its closest position to the Equator.

Clear correlations are evident between the temporal and spatial variability in the COT and the seasonality and spatial distribution of the SWD belt. A clear minimum in COT $(<5)$ was seen in the area between the Equator and $2^{\circ} \mathrm{N}$ from May to August (Fig. 5b). The CF's temporal evolution was similar, but with a slight southward shift in the location of the minimum synclines toward the cold tongue (Fig. 5c). To quantify the strength and robustness of the correlations, we extracted the central part around our study area (between latitudes $3^{\circ} \mathrm{N}$ and $6^{\circ} \mathrm{S}$ ) of the COT and CF Hovmöller matrixes and checked the correlations for a gradual shift between each of them and the SWD matrix. The 2-D correlation was calculated for each displacement between the two matrixes (Fig. 6). Both COT and CF matrixes showed that the peak in correlations with the SWD corresponds to no shift in time. The peak correlation with COT was $R=0.74$, showing a perfect match with the SWD (no shift in latitude or time). The peak correlation with CF was $R=0.75$, corresponding to a shift of $2^{\circ}$ southward relative to the SWD field, and suggesting a stronger link to the cold SST south of the Equator. Note the oscillations along the time axis indicating a peak in the correlations when the shift matches 1 year. A secondary maximum is shown when the latitudinal shift is large enough to correlate with the marine stratocumulus decks in the south. A minimum is shown when the latitudinal shift to the north is large enough to correlate over the opposite trends of the ITCZ.

By zooming in over the SWD region, the link between SST, meridional gradient of SST (gradSST), and SWD with time was investigated (Fig. 7), focusing only on the area of the most significant SWD in the central Atlantic (latitudes/longitudes: $0-2^{\circ} \mathrm{N} / 20-10^{\circ} \mathrm{W}$, green square in Fig. 4a). Monthly mean SST (Fig. 7a) ranged from $\sim 29^{\circ} \mathrm{C}$ around March-May to $\sim 24^{\circ} \mathrm{C}$ around July-August. The changes in 

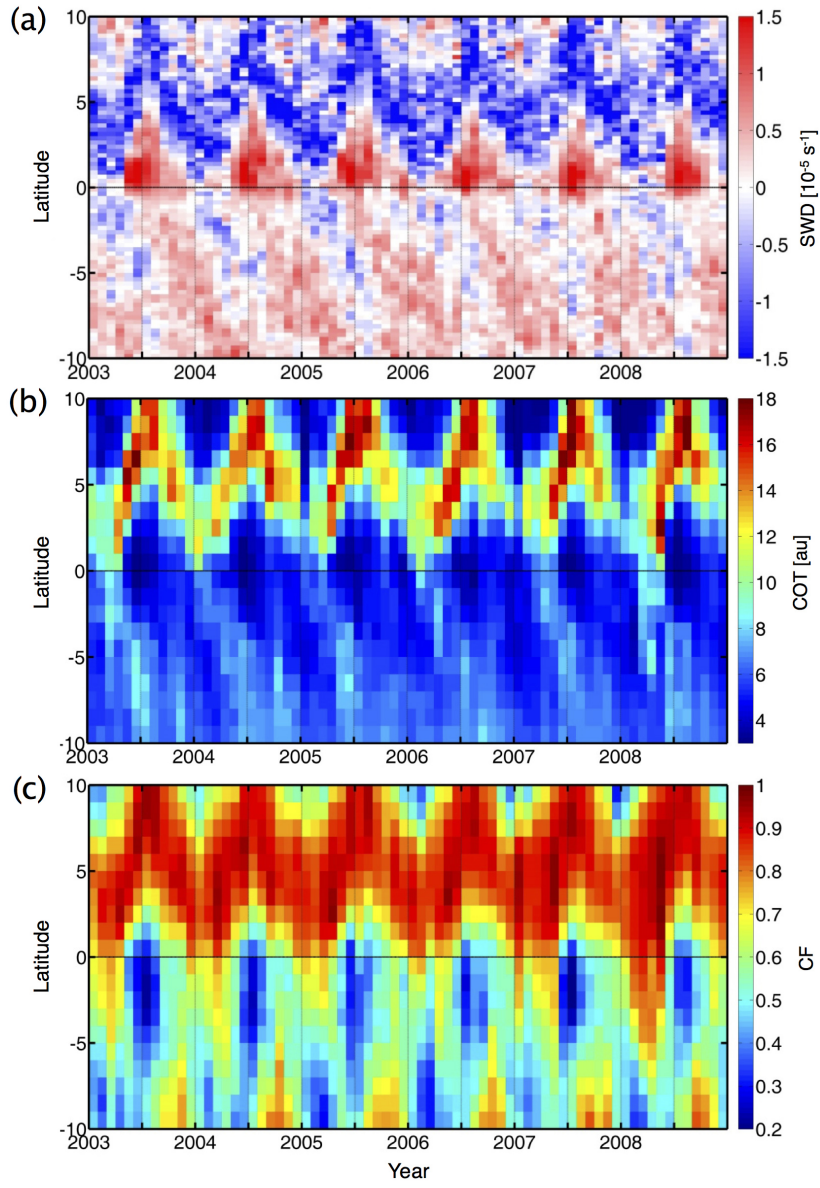

Figure 5. Latitude-time Hovmöller diagrams (2003-2008) of zonal and monthly mean (a) surface wind divergence $\left(10^{-5} \mathrm{~s}^{-1}\right)$, (b) cloud optical thickness, and (c) cloud fraction. The central Atlantic section $\left(20-10^{\circ} \mathrm{W}\right)$ averaged for these Hovmöller diagrams is in the yellow square in Fig. 4a.

SST with time showed a relatively rapid cooling period compared to the warming period, in agreement with the known dynamics of the equatorial Atlantic cold tongue (Okumura and Xie, 2004). The sharpest SST gradients (Fig. 7b) appeared about a month before the mean SST minimum (i.e., June or July). Here, positive values of gradSST reflected SST warming from the Equator northward. Temporal variability in SWD (Fig. 7c) behaved like a combination of the SST and meridional gradSST fields. It had rapid evolving and slow decaying times, similar to the SST field, but its maximal values clearly correlated in time with the gradSST peaks (June or July, marked by red-shaded columns).

The most pronounced SWD belt appeared (June/July depending on the year, Fig. 7) before the beginning of the coldest SST phase (July/August). This trend could be related to the northward migration of the ITCZ. During the stage at which the equatorial cold tongue begins to evolve, the ITCZ location is relatively closer to the Equator, and therefore the ratio between the temperature differences and distance from the Equator northward (i.e., gradSST) is the largest. When the cold tongue is well established and the ITCZ is in a northern-most position (July/August), both gradSST and SWD are on their descending branch. When the ITCZ is close to the Equator (December-March), the equatorial SST is warm, gradSST is at its minimal values, and the SWD exhibits its minimal (negative) values (i.e., convergence).

The mean COT over the location of the prominent SWD belt (between 0 and $2^{\circ} \mathrm{N}$ latitudes) varied between 2 and 13 (Fig. 7d), and the mean CF over this region ranged between 0.4 and 0.9 (Fig. 7e). Both cloud characteristics showed a distinct seasonal link to the activity of ocean-atmosphere dynamic features. The boreal summer seasons with cold SST, sharp gradSST, and strong SWD were characterized by optically thinner clouds (low COT) and a decrease in cloud cover. On the other hand, the boreal winter and spring seasons were characterized by warm SST, mild gradSST, and negative SWD and therefore optically thicker clouds (high COT) with larger cloud cover. The evolution of the Atlantic cold tongue and the SWD belt is illustrated by a decrease in SST, increase in gradSST, and a sharp transition to minima in $\mathrm{COT}$ and $\mathrm{CF}$.

The links between gradSST to SWD and the associated cloud optical thickness were further examined during the boreal summer months. Daily data (in $1^{\circ}$ ) were used for the period of JJA 2007, for the area between $0-3^{\circ} \mathrm{N}$ and 30 $10^{\circ} \mathrm{W}$ (to ensure a large enough data set). Clear positive correlations are shown between gradSST $\left(R^{2}=0.75\right)$ and SWD and inverse correlations with COT (Fig. 8). We estimated that, in this case and at this resolution, COT decreased by $\sim 0.57 \pm 0.1$ for increase of $1 \times 10^{-5} \mathrm{~s}^{-1}$ in SWD.

\section{Summary and discussion}

The equatorial Atlantic SWD belt spans over the central Atlantic between the Equator and $2^{\circ} \mathrm{N}$ latitude and is characterized by a mean monthly divergence higher than $\sim 1.5 \times$ $10^{-5} \mathrm{~s}^{-1}$ (for a resolution of $1^{\circ} \times 1^{\circ}$ ), which is of the same order of magnitude as (but opposite sign to) the average ITCZ convergence. It is most pronounced from May to August. Here we show a positive correlation and tight connection in space and time between the (large-scale) distribution of sharp mean monthly gradSST and SWD. These results support vertical mixing as the mechanism responsible (Wallace et al., 1989) for formation of the SWD belt over the northern SST front of the Atlantic cold tongue.

Investigating the link of cloud properties to the SWD and cold tongue, we show that the COT correlates in space and time with gradSST and SWD, whereas CF correlates better with SST. We show that the minimum COT is located exactly over the sharp SST gradient and the SWD belt (0$2^{\circ} \mathrm{N}$ ), while the area of minimum cloud cover overlaps the cold tongue $\left(5^{\circ} \mathrm{S}-1^{\circ} \mathrm{N}\right)$. Temporal analysis focusing on the SWD belt only showed similar results (Fig. 7). Shallow cu- 

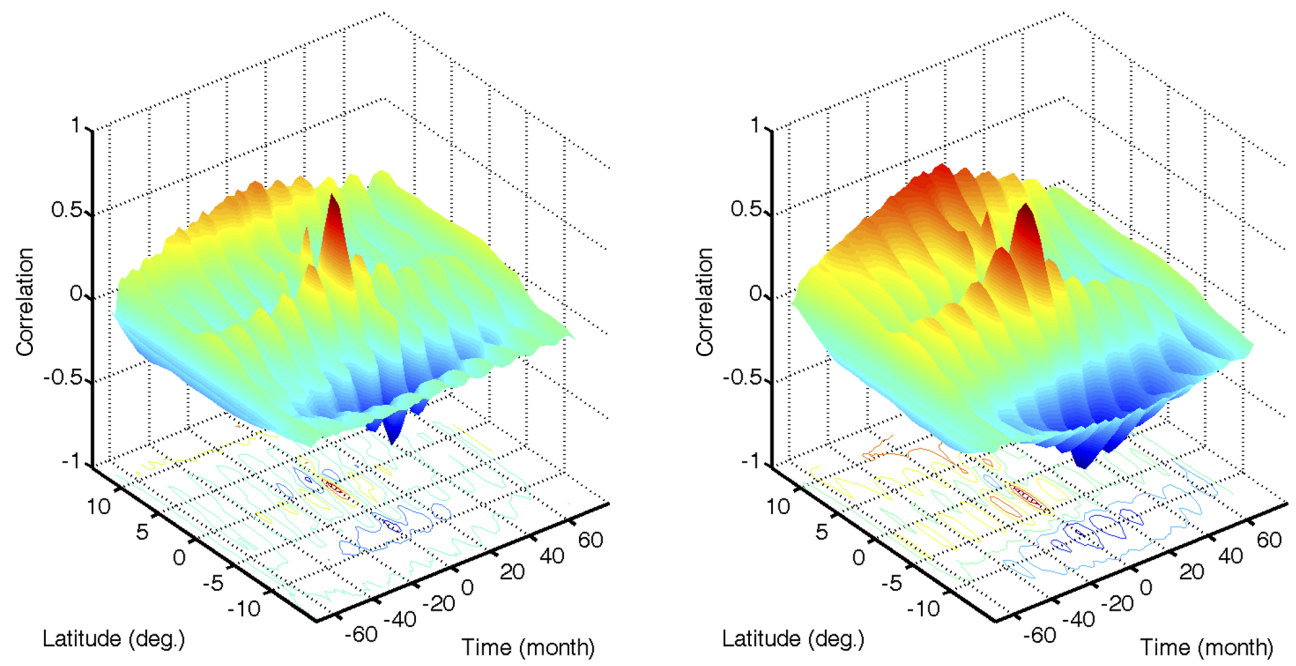

Figure 6. Correlation matrixes between the Hovmöller diagrams of the surface wind divergence (SWD, with a negative sign) and the cloud optical thickness (COT, left) and the cloud fraction (CF, right). Both matrixes show that the correlation peaks correspond to no shift in time ( $x$ axis). The peak correlation with COT, $R=0.74$, also corresponds to no shift in latitude ( $y$ axis). The peak correlation with $\mathrm{CF}, R=0.75$, corresponds to a $2^{\circ}$ southward shift relative to the SWD field, suggesting a stronger link to the cold SST over the Equator than to meridional gradient of SST (gradSST).

(a)

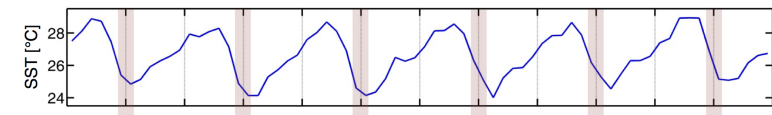

(b)

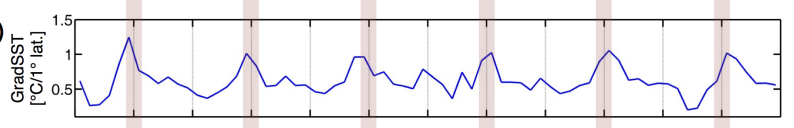

(c)

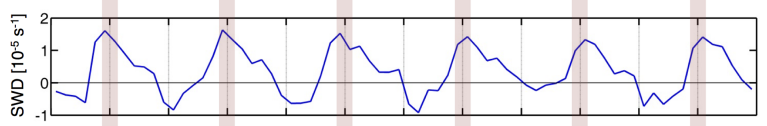

(d)

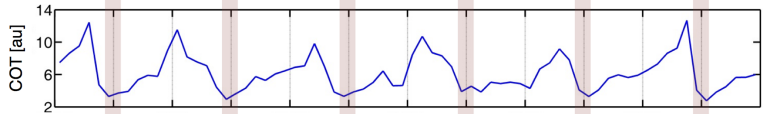

(e)

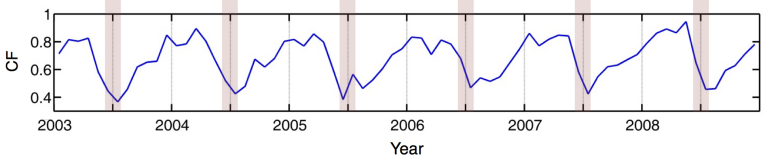

Figure 7. Mean monthly time series (2003-2008) of oceanic and atmospheric dynamic state and cloud properties along the equatorial Atlantic (latitudes/longitudes: $0-2^{\circ} \mathrm{N} / 20-10^{\circ} \mathrm{W}$ ). The presented fields are (a) sea-surface temperature (SST), (b) meridional gradient of SST, (c) surface wind divergence (SWD), (d) total cloud optical thickness (COT), and (e) daytime cloud cover fraction (CF, in normalized units between 0 and 1 ).

mulus clouds, which are the dominant clouds in the SWD region, form under moderate SST conditions $\left(\sim 24-27^{\circ} \mathrm{C}\right)$ and their coverage was positively correlated with SST. The cumulus cloud COT and CF were highly correlated with the magnitude of the SWD (Figs. 7, 8).

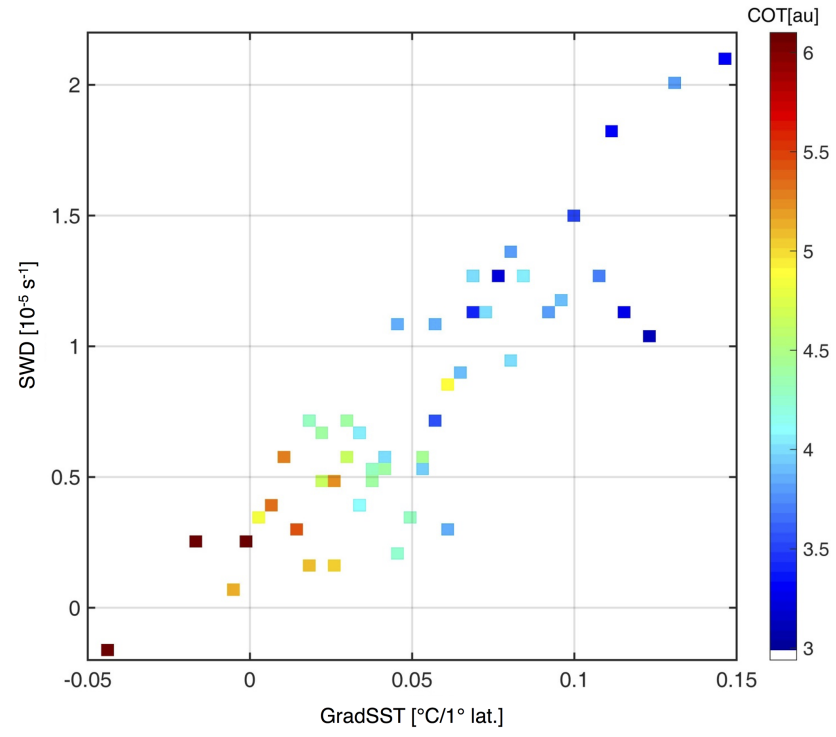

Figure 8. Three-dimensional scatter plot displaying the link between daily values of gradSST $\left({ }^{\circ} \mathrm{C} / 1^{\circ}\right.$ lat.), SWD $\left(10^{-5} \mathrm{~s}^{-1}\right)$ and COT (au) over the SWD belt (latitudes/longitudes: $0-3^{\circ} \mathrm{N} / 30$ $10^{\circ} \mathrm{W}$ ), during June, July, and August 2007. This plot illustrates the robustness of the correlations between the three parameters using a daily resolution. The relevant data are divided into 50 bins that contain an equal number of samples.

Previous studies have shown a gradual decrease in cloud cover along the subtropical-to-tropical cloud transition (Sandu et al., 2010; Muhlbauer et al., 2014), with a minimum over the trade cumulus region. But in general, this transition 
has received little attention in observational studies and climate models find it difficult to correctly represent its properties. The subtropical-to-tropical cloud transition was recently investigated in the northeastern Pacific Ocean to provide a framework for evaluating climate-model results against observations (Karlsson et al., 2010; Teixeira et al., 2011). Over the Atlantic Ocean, the belt bounded by the Equator (in the south) and the ITCZ is better defined, and therefore the SWD and its links to cloud properties are clearer. Our results suggest that this belt should be considered a separate entity of the southern branch of the Hadley cell over the Atlantic. A better understanding of the essential dynamic features and their link to cloud properties over this narrow strip may help improve low-level cloud representation in climate models. The appearance of the SWD belt during the boreal summer over the Atlantic and the quantitative link between its magnitude and COT as presented here can be used for cloud parameterizations in climate models as well as for model validation for cloud-resolving ones.

Acknowledgements. The research leading to these results received funding from the European Research Council under the European Union's Seventh Framework Programme (FP7/20072013)/ERC grant agreement no. 306965.

Edited by: R. Krishnan

\section{References}

Albrecht, B. A., Bretherton, C. S., Johnson, D., Scubert, W. H., and Frisch, A. S.: The Atlantic Stratocumulus Transition Experiment - ASTEX, B. Am. Meteorol. Soc., 76, 889-904, doi:10.1175/1520-0477(1995)076<0889:TASTE>2.0.CO;2, 1995.

Bretherton, C. and Wyant, M.: Moisture transport, lowertropospheric stability, and decoupling of cloud-topped boundary layers, J. Atmos. Sci., 54, 148-167, doi:10.1175/15200469(1997)054<0148:MTLTSA>2.0.CO;2, 1997.

Chelton, D. and Xie, S.: Coupled ocean-atmosphere interaction at oceanic mesoscales, Oceanography, 23, 52-69, doi:10.5670/oceanog.2010.05, 2010.

Chelton, D. B., Esbensen, S. K., Schlax, M. G., Thum, N., Freilich, M. H., Wentz, F. J., Gentemann, C. L., McPhaden, M. J., and Schopf, P. S.: Observations of coupling between surface wind stress and sea surface temperature in the Eastern Tropical Pacific, J. Climate, 14, 1479-1498, doi:10.1175/15200442(2001)014<1479:OOCBSW>2.0.CO;2, 2001.

Deser, C., Wahl, S., and Bates, J.: The influence of Sea surface temperature gradients on stratiform cloudiness along the equatorial front in the Pacific ocean, J. Climate, 6, 1172-1180, doi:10.1175/1520-0442(1993)006<1172:TIOSST>2.0.CO;2, 1993.

de Szoeke, S. P., Bretherton, C. S., Bond, N. A., Cronin, M. F., and Morley, B. M.: EPIC 95W observations of the Eastern Pacific atmospheric boundary layer from the cold tongue to the ITCZ, J. Atmos. Sci., 62, 426-442, doi:10.1175/JAS-3381.1, 2005.
Draper, D. W. and Long, D. G.: Evaluating the effect of rain on SeaWinds scatterometer measurements, J. Geophys. Res., 109, C0205, doi:10.1029/2002JC001741, 2004.

Düing, W., Hisard, P., Katz, E., Meincke, J., Miller, L., Moroshkin, K. V., Philander, G., Ribnikov, A. A., Voigt, K., and Weisberg, R.: Meanders and long waves in the equatorial Atlantic, Nature, 257, 280-284, doi:10.1038/257280a0, 1975.

Esaias, W. E., Abbott, M. R., Barton, I., Brown, O. B., Campbell, J. W., Carder, K. L., Clark, D. K., Evans, R. H., Hoge, F. E., Gordon, H. R., Balch, W. M., Letelier, R., and Minnett, P. J.: An overview of MODIS capabilities for Ocean Sci. observations, IEEE T. Geosci. Remote, 36, 1250-1265, doi:10.1109/36.701076, 1998.

Hashizume, H., Xie, S.-P., Liu, W. T., and Takeuchi, K.: Local and remote atmospheric response to tropical instability waves: a global view from space, J. Geophys. Res., 106, 10173-10185, doi:10.1029/2000JD900684, 2001.

Hastenrath, S. and Lamb, P.: On the dynamics and climatology of surface flow over the Equatorial oceans, Tellus A, 30, 436-448, doi:10.3402/tellusa.v30i5.10387, 1978.

Hayes, S. P., McPhaden, M. J., and Wallace, J. M.: The influence of sea-surface temperature on surface wind in the Eastern Equatorial Pacific: weekly to monthly variability, J. Climate, 2, 1500-1506, doi:10.1175/15200442(1989)002<1500:TIOSST>2.0.CO;2, 1989.

$\mathrm{Hu}, \mathrm{Y} ., \mathrm{Li}, \mathrm{D}$., and Liu, J.: Abrupt seasonal variation of the ITCZ and the Hadley circulation, Geophys. Res. Lett., 34, L18814, doi:10.1029/2007GL030950, 2007.

Karlsson, J., Svensson, G., Cardoso, S., Teixeira, J., and Paradise, S.: Subtropical cloud-regime transitions: boundary layer depth and cloud-top height evolution in models and observations, J. Appl. Meteorol., 49, 1845-1858, doi:10.1175/2010JAMC2338.1, 2010.

Legeckis, R.: Long waves in the eastern equatorial pacific ocean: a view from a geostationary satellite, Science, 197, 1179-1181, doi:10.1126/science.197.4309.1179, 1977.

Lindzen, R. S. and Nigam, S.: On the role of sea surface temperature gradients in forcing low-level winds and convergence in the tropics, J. Atmos. Sci., 44, 2418-2436, doi:10.1175/15200469(1987)044<2418:OTROSS>2.0.CO;2, 1987.

Mansbach, D. K. and Norris, J. R.: Low-level cloud variability over the equatorial cold tongue in observations and models, J. Climate, 20, 1555-1570, doi:10.1175/JCLI4073.1, 2007.

Mitchell, T. and Wallace, J.: The annual cycle in equatorial convection and sea surface temperature, J. Climate, 5, 1140-1156, doi:10.1175/1520-0442(1992)005<1140:TACIEC>2.0.CO;2, 1992.

Muhlbauer, A., McCoy, I. L., and Wood, R.: Climatology of stratocumulus cloud morphologies: microphysical properties and radiative effects, Atmos. Chem. Phys., 14, 6695-6716, doi:10.5194/acp-14-6695-2014, 2014.

Myers, T. A. and Norris, J. R.: Observational evidence that enhanced subsidence reduces subtropical marine boundary layer cloudiness, J. Climate, 26, 7507-7524, doi:10.1175/JCLI-D-1200736.1, 2013.

Okumura, Y. and Xie, S. P.: Interaction of the Atlantic equatorial cold tongue and the African monsoon, J. Climate, 17, 3589-3602, doi:10.1175/15200442(2004)017<3589:IOTAEC>2.0.CO;2, 2004. 
Platnick, S., King, M. D., Ackerman, S. A., Menzel, W. P., Baum, B. A., Riédi, J. C., and Frey, R. A.: The MODIS cloud products: algorithms and examples from Terra, IEEE T. Geosci. Remote, 41, 459-473, doi:10.1109/TGRS.2002.808301, 2003.

Risien, C. M. and Chelton, D. B.: A global climatology of surface wind and wind stress fields from eight years of QuikSCAT scatterometer data, J. Phys. Oceanogr., 38, 23792413, doi:10.1175/2008JPO3881.1, 2008.

Sandu, I., Stevens, B., and Pincus, R.: On the transitions in marine boundary layer cloudiness, Atmos. Chem. Phys., 10, 2377-2391, doi:10.5194/acp-10-2377-2010, 2010.

Small, R. J., Xie, S.-P., Wang, Y., Esbensen, S. K., and Vickers, D.: Numerical Simulation of Boundary Layer Structure and CrossEquatorial Flow in the Eastern Pacific* , J. Atmos. Sci., 62, 18121830, doi:10.1175/JAS3433.1, 2005.

Small, R. J., de Szoeke, S. P., Xie, S. P., O’Neill, L., Seo, H., Song, Q., Cornillon, P., Spall, M., and Minobe, S.: Air-sea interaction over ocean fronts and eddies, Dynam. Atmos. Oceans, 45, 274319, doi:10.1016/j.dynatmoce.2008.01.001, 2008.

Spencer, M. W., Wu, C., Long, D. G., and Member, S.: Improved resolution backscatter measurements with the seawinds pencil-beam scatterometer, IEEE T. Geosci. Remote, 38, 89-104, doi:10.1109/36.823904, 2000.

Teixeira, J., Cardoso, S., Bonazzola, M., et al.: Tropical and subtropical cloud transitions in weather and climate prediction models: the GCSS/WGNE Pacific Cross-Section Intercomparison (GPCI), J. Climate, 24, 5223-5256, doi:10.1175/2011JCLI3672.1, 2011.

Thum, N., Esbensen, S., Chelton, D. B. and McPhaden, M. J.: Air-sea heat exchange along the northern sea surface temperature front in the eastern tropical Pacific, J. Climate, 15, 3361-3378, doi:10.1175/1520-0442(2002)015<3361:Asheat>2.0.Co;2, 2002.
Wallace, J. M., Mitchell, T. P., and Deser, C.: The influence of sea-surface temperature on surface wind in the Eastern Equatorial Pacific: seasonal and interannual variability, J. Climate, 2, 1492-1499, doi:10.1175/15200442(1989)002<1492:TIOSST>2.0.CO;2, 1989.

Wood, R.: Stratocumulus clouds, Mon. Weather Rev., 140, 23732423, doi:10.1175/MWR-D-11-00121.1, 2012.

Wu, Q. and Bowman, K. P.: Multiyear satellite observations of the atmospheric response to Atlantic tropical instability waves, J. Geophys. Res., 112, D19104, doi:10.1029/2007JD008627, 2007.

Wyant, M. C., Bretherton, C. S., Rand, H. A., and Stevens, D. E.: Numerical simulations and a conceptual model of the stratocumulus to trade cumulus transition, J. Atmos. Sci., 54, 168-192, doi:10.1175/1520-0469(1997)054<0168:NSAACM>2.0.CO;2, 1997.

Xie, S., Ishiwatari, M., Hashizume, H., and Takeuchi, K.: Coupled ocean-atmospheric waves on the equatorial front, Geophys. Res. Lett., 25, 3863, doi:10.1029/1998GL900014, 1998.

Xie, S. P.: Satellite observations of cool ocean-atmosphere interaction, B. Am. Meteorol. Soc., 85, 195-208, doi:10.1175/BAMS85-2-195, 2004.

Zhang, G. J. and McPhaden, M. J.: The Relationship between Sea Surface Temperature and Latent Heat Flux in the Equatorial Pacific, J. Climate, 8, 589-605, doi:10.1175/15200442(1995)008<0589:TRBSST>2.0.CO;2, 1995.

Zhang, Y., Stevens, B., Medeiros, B., and Ghil, M.: Low-cloud fraction, lower-tropospheric stability, and large-scale divergence, J. Climate, 22, 4827-4844, doi:10.1175/2009JCLI2891.1, 2009. 